\title{
Regulation of B cell activating factor (BAFF) receptor expression by NF- $\kappa B$ signaling in rheumatoid arthritis $B$ cells
}

\author{
Yun-Ju Woo ${ }^{1 *}$, Bo-Young Yoon ${ }^{2 *}$, Joo-Yeon Jhun ${ }^{1}$, \\ Hye-Jwa Oh${ }^{1}$, Sewon $\mathrm{Min}^{3}$, Mi-La Cho ${ }^{1,4}$, \\ Sung-Hwan Park ${ }^{1}$, Ho-Youn Kim ${ }^{1}$ and Jun-Ki Min ${ }^{1,4}$ \\ ${ }^{1}$ The Rheumatism Research Center \\ Catholic Research Institute of Medical Science \\ The Catholic University of Korea \\ Seoul 137-040, Korea \\ ${ }^{2}$ Department of Internal Medicine \\ Inje University Ilsan Paik Hospital \\ Seoul 411-706, Korea \\ ${ }^{3}$ Case Western Reserve University \\ Frances Payne Bolton School of Nursing \\ Cleveland, U.S.A. \\ ${ }^{4}$ Corresponding authors: Tel, 82-2-2258-7467; \\ Fax, 82-2-599-4287; E-mail, iammila@ catholic.ac.kr (M.L.C) \\ Tel, 82-32-340-7016; Fax, 82-32-340-2669; \\ E-mail, rmin6403@ hanmail.net (J.K.M) \\ *These authors contributed equally to this work. \\ DOI 10.3858/emm.2011.43.6.038
}

Accepted 15 April 2011

Available Online 25 April 2011

Abbreviations: APRIL, a proliferation-inducing ligand; BAFF, B cell activation factor; BAFF-R, BAFF receptor; BCMA, B cell maturation antigen; BCR, B cell receptor; MMP, matrix metalloproteinase; OA, osteoarthritis; PBMC, peripheral blood mononuclear cells; RA, rheumatoid arthritis; TACl, transmembrane activator and calcium modulator and cyclophilin ligand interactor

\begin{abstract}
$B$ cells play an important role in the pathogenesis of rheumatoid arthritis (RA). High levels of $B$ cell activating factor (BAFF) are detected in autoimmune diseases. BAFF and BAFF receptor (BAFF-R) are expressed in $B$ and $T$ cells of RA synovium. The study was undertaken to identify the NF- $k B$ signal pathway involved in the induction of BAFF-R in human $B$ cells. Immunohistochemical staining of NF- $\kappa$ B p $65, N F-\kappa B$ p50, BAFF, and BAFF-R was performed on sections of synovium from severe and mild RA and osteoarthritis (OA) patients. Peripheral blood mononuclear cells (PBMCs) were isolated from control and RA patients and $B$ cells were isolated from controls. BAFF- $R$ was analyzed by flow cytometry, realtime PCR and confocal staining after treatment with NF- $\kappa B$ inhibitors. NF- $\kappa B$
\end{abstract}

p65, NF- $k B$ p50, BAFF, and BAFF-R were highly expressed in severe RA synovium relative to mild RA synovium or OA synovium. BAFF-R expression was reduced by NF- $k B$ inhibitors in PBMCs and $B$ cells from normal controls. We also showed reduction in expression of BAFF-R via inhibition of the NF- $k B$ pathway in PBMCs of RA patients. BAFF/BAFF-R signaling is an important mechanism of pathogenesis in RA and that $B A F F-R$ reduction by NF- $k B$ blocking therapy is another choice for controlling $B$ cells in autoimmune diseases such as RA.

Keywords: B-cell activation factor receptor; B-cell activating factor; B-lymphocytes; NF-kappa B; rheumatoid arthritis

\section{Introduction}

B cell activating factor (BAFF), a member of the tumor necrosis factor family and also known as BLys, TALL-1, zTNF4, or THANK, is a critical cytokine in peripheral $B$ cell survival during primary development and homeostasis (Rahman et al., 2003; Matsushita et al., 2007). BAFF is mainly secreted by monocytes, dendritic cells, and T cells. (Rahman et al., 2003; Rahman and Manser, 2004; Zhang et al., 2005; Matsushita et al., 2007). BAFF stimulation also results in prolonged survival of mature resting B cells (Do et al., 2000; Gross et al., 2001). The addition of BAFF to cultures of $B$ cells augments class switching of those cells from IgM to IgG (Litinskiy et al., 2002).

In humans, high levels of BAFF are detectable in the blood of a percentage of patients with autoimmune diseases, particularly systemic lupus erythematosus and Sjögren's syndrome (Nakajima et al., 2007; Groom et al., 2002) Controlling BAFF may be a potential treatment in $B$ cell-related autoimmune diseases.

BAFF binds to three receptors, BAFF-R, transmembrane activator and calcium modulator and cyclophilin ligand interactor (TACl), and B cell maturation Ag (BCMA) (Rahman et al., 2003; Rahman and Manser, 2004; Zhang et al., 2005; Matsushita et al., 2007; Kim et al., 2009). TACl and BCMA also bind a closely related cytokine, a proliferation-inducing ligand (APRIL). Although all three receptors bind to BAFF, BAFF-R appears to be the most important receptor for mature $B$ cell survival 

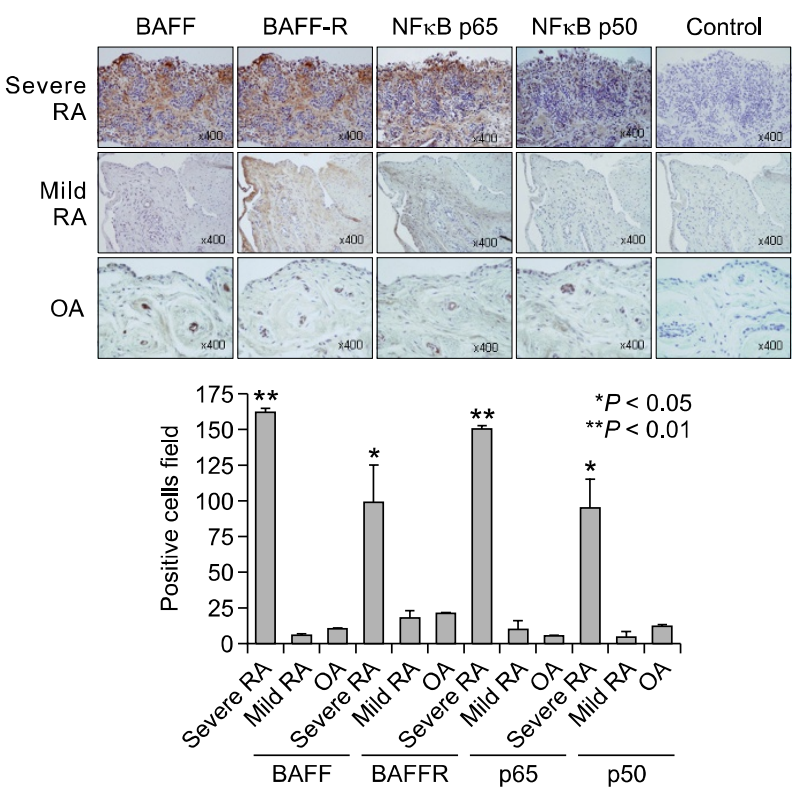

Figure 1. Expression of BAFF, BAFF-R, NF- $\kappa B$ p65, and NF- $\kappa B$ p50 are significantly increased in RA synovium. Synovial tissue sections were analyzed using immunohistochemistry and monoclonal antibodies to BAFF, BAFF-R, NF- $\kappa$ B p 65 and NF- $\kappa$ B p50.

and homeostasis in peripheral $B$ cells. BAFF-R is the only known BAFF receptor detectable on most mature $B$ cells. Furthermore, anti-BAFF-R monoclonal antibodies completely inhibited BAFF-mediated costimulation of $B$ cells ( $\mathrm{Ng}$ et al., 2004). A/WySnJ mice, containing a mutation in BAFF-R, exhibit a phenotype that is similar to BAFF-deficient mice (Mayne et al., 2008).

Nuclear factor (NF)-kB controls the expression of cytokines IL-1 $\beta$ and TNF $\alpha$, the essential mediators of inflammation in rheumatoid arthritis (RA). Many conventional anti-inflammatory and antirheumatic drugs, including glucocorticoids, aspirin, sodium salicylate and sulfasalazine, are inhibitors, albeit not not very potent ones, of NF- $k B$ activation. Some studies have shown that more specific inhibitors of NF- $k B$ reduced the severity of arthritis and inhibited the production of IL-1 $\beta$ and TNF $\alpha$ in several arthritis animal models (Miagkov et al., 1998; Tomita et al., 1999; Makarov, 2001; Jung et al., 2010).

Following B lymphocyte depletion with the anti-CD20 antibody rituximab in patients with RA, a positive clinical response occurred that correlated with a significant drop in the levels of C-reactive protein and autoantibodies (Cambridge et al., 2003). In addition, cells of the synovial sublining expressed BAFF. BAFF and BAFF-R were expressed in $B$ and $T$ cells extracted from RA synovium (Nakajima et al., 2007). These results showed a role for B lymphocytes in the patho-

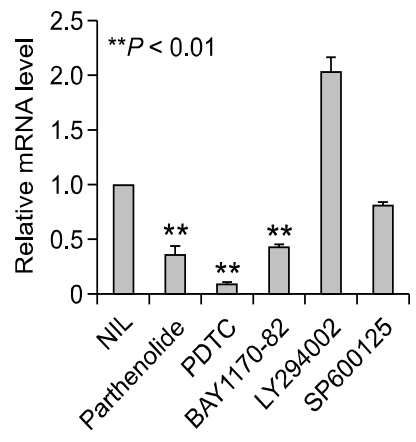

Figure 2. Effects of signal pathway inhibitors on BAFF-R expression in B cells isolated from healthy volunteers. PBMCs were cultured for $24 \mathrm{~h}$ with parthenolide $(10 \mu \mathrm{M})$, PDTC $(0.5 \mu \mathrm{M})$, BAY1170-82 $(10 \mu \mathrm{M})$, LY294002 $(1 \mu \mathrm{M})$, or SP900125 $(10 \mu \mathrm{M})$. Analysis of BAFF-R expression was performed using real time PCR. The results were confirmed by four independent experiments.

genesis of RA. Inhibition of NF- $k B$ reduced production of inflammatory cytokines IL-1 and TNF $\alpha$ in the RA model. NF- $k$ B might also control $B$ cell function via BAFF and BAFF-R. This result would suggest that not only $T$ helper cells but also $B$ cells are connected by NF- $k B$ pathways in RA.

Excessive BAFF signaling through BAFF-R results in prolonged $B$ cell survival and costimulates $B$ and T cells. Instead of blocking BAFF-R or decreasing BAFF, reduction of BAFF-R numbers would also, theoretically, reduce the effects of BAFF-BAFF-R signaling in inflammatory autoimmune diseases.

We redefined the expression of BAFF-R in RA synovium and investigated the relation of BAFF-R and NF- $k B$. We show the possibility of controlling the amounts of BAFF-R and reducing the effects of BAFF-R signaling through NF- $k$ B inhibition.

\section{Results}

\section{Increased expression of BAFF-R in the RA synovium}

To examine BAFF and BAFF-R expression in synovium, samples of severe RA, mild RA and OA synovium were immunostained with specific antibodies for these proteins. BAFF and BAFF-R were expressed more strongly in synovial tissue sections derived from patients with severe RA than in sections from patients with mild RA or OA. To determine NF- $k B$ p65 and NF- $k B$ p50 expression, tissues were immunostained with specific antibodies for these proteins. The immunostaining patterns of $N F-k B$ p65 and NF- $k B$ p50 were similar to those for BAFF-R (Figure 1). 
A
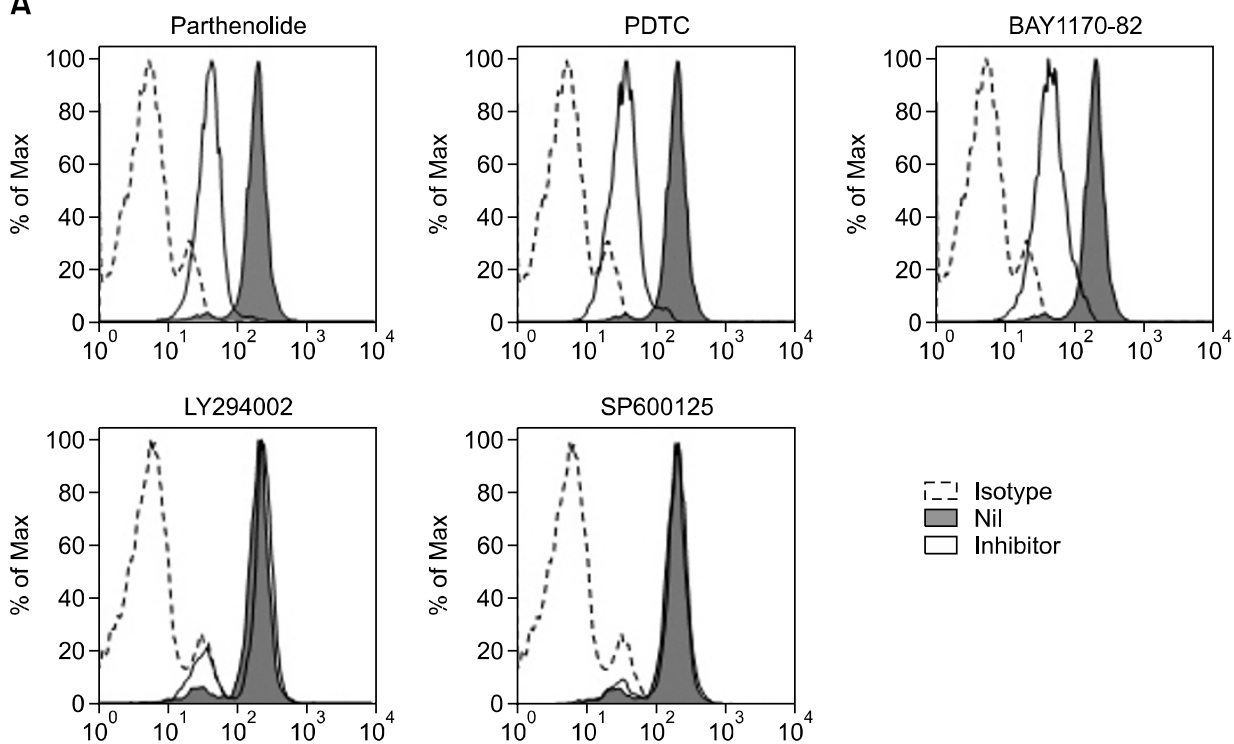

BAFF-R-PE

B
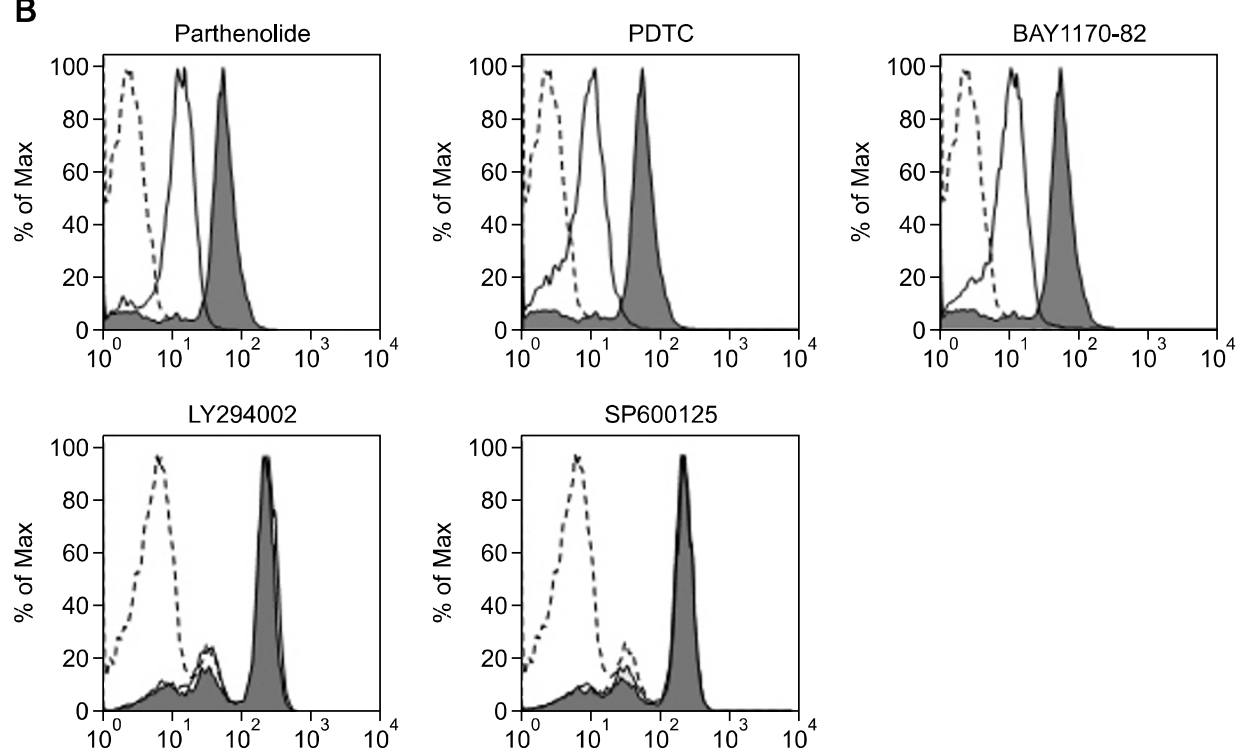

BAFF-R-PE

Figure 3. Effects of signal pathway inhibitors on BAFF-R expression on PBMC (A) and $B$ cells (B) isolated from healthy controls. Cells were cultured with parthenolide $(10 \mu \mathrm{M})$, PDTC $(0.5 \mu \mathrm{M})$, BAY1170-82 $(10 \mu \mathrm{M})$, LY294002 $(1 \mu \mathrm{M})$, or SP900125 $(10 \mu \mathrm{M})$ for $24 \mathrm{~h}$. Analysis of BAFF-R expression was performed using FACS. The results were confirmed by four independent experiments.

\section{Effect of inhibition of signaling pathways on expression of BAFF-R in healthy PBMCs}

To determine the effect on BAFF-R expression of inhibition of several signal pathways, PBMCs isolated from healthy volunteers were cultured for $24 \mathrm{~h}$ with parthenolide $10 \mu \mathrm{M}$, PDTC $0.5 \mu \mathrm{M}$, BAY1170-82 $10 \mu \mathrm{M}$, LY294002 $1 \mu \mathrm{M}$, or SP900125 $10 \mu \mathrm{M}$, and the level of BAFF-R mRNA expression was measured by real time PCR. BAFF-R was reduced by $N F-\kappa B$ inhibitors parthenolide, PDTC, and BAY1170-82 (Figure 2). And the above conditions, cells were stained with $P E-c o n j u g a t e d$ antihuman BAFF-R. We did not stain for B cells because BAFF-R is expressed mainly on $B$ cells. The expression of BAFF-R was reduced by the NF- $k$ B inhibitors. In contrast, LY294002, a phosphatidylinositol-3 kinase inhibitor, and SP900125, a 


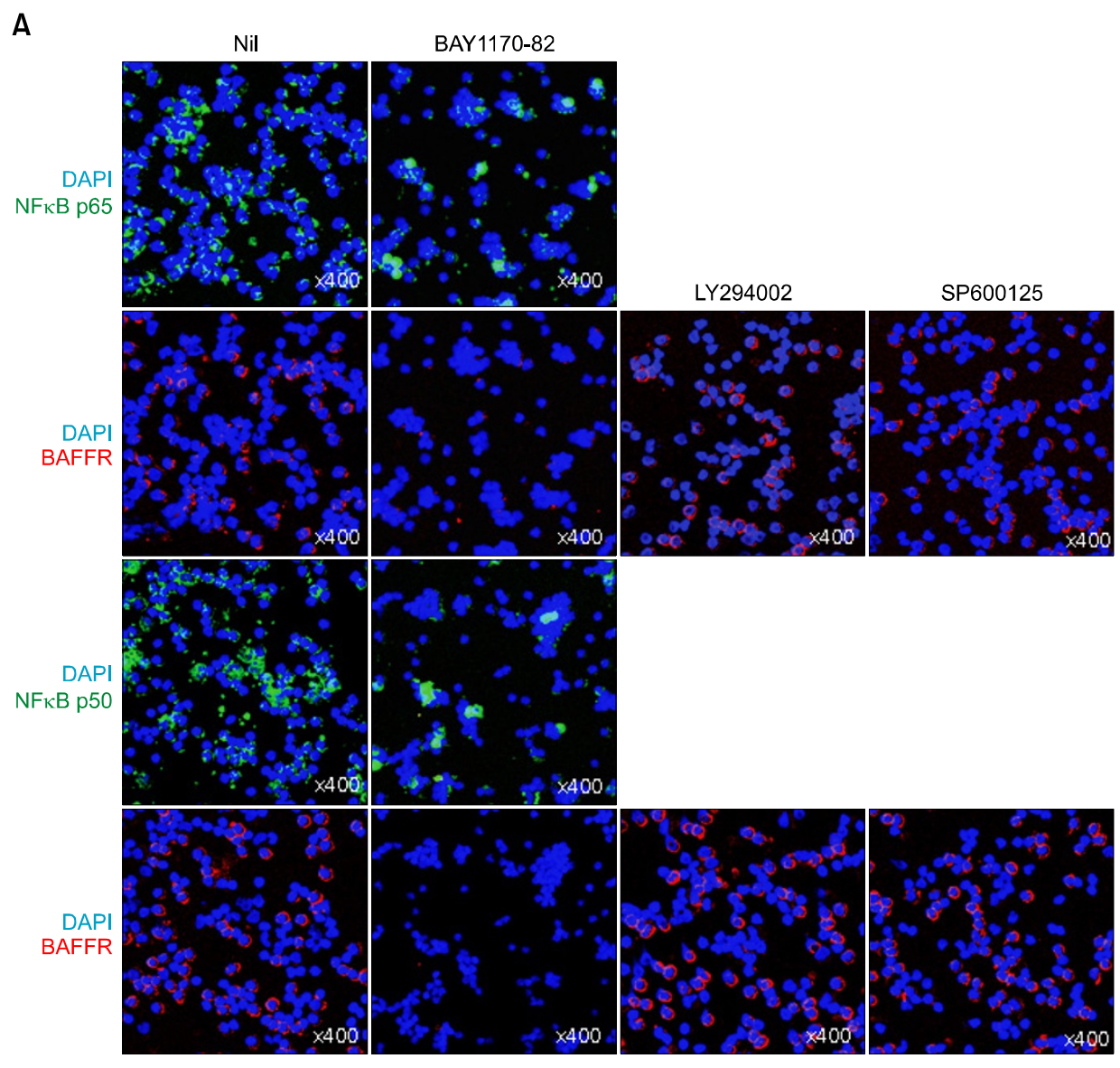

B

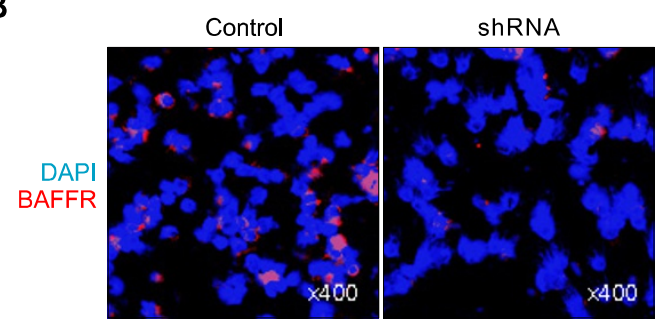

C

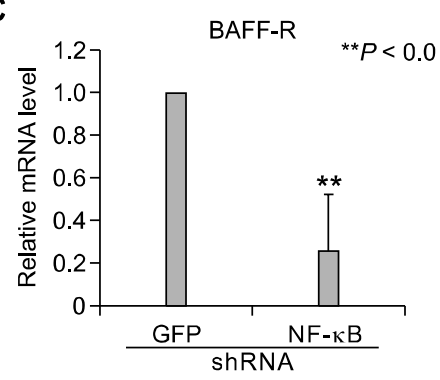

Figure 4. (A) B cells cultured with BAY1170-82 (10 LY294002 (1 or SP900125 (10 for 24h were examined bv immunofluorescence staining of BAFF-R, NF-p65 and NF-p50. (B and C) B cells treated with shRNAs $(2 \mathrm{~g} / \mathrm{ml})$ to $\mathrm{NF}-\kappa \mathrm{B}$ or GFP (negative control) were analyzed by confocal microscopy (B) and real-time PCR (C). ${ }^{*} P<0.01$.

JNK inhibitor, had no effect on BAFF-R expression (Figure $3 A$ ). Next, we isolated peripheral $B$ cells using $B$ cell isolation kit II and cultured them with parthenolide $10 \mu \mathrm{M}$, PDTC $0.5 \mu \mathrm{M}$, BAY1170-82 10 $\mu \mathrm{M}$, LY294002 $1 \mu \mathrm{M}$, or SP900125 $10 \mu \mathrm{M}$. After 24 $h$, cells were stained with PE-conjugated antihuman BAFF-R. There was also a tendency towards a reduced expression of BAFF- $R$ on $B$ cells stimulated with $\mathrm{NF}-\kappa \mathrm{B}$ inhibitors (Figure $3 \mathrm{~B}$ ). The results were confirmd by four independent experi- ments. Next, we were checked the level of NF- $k B$ of $B$ cells after treatement of $N F-\kappa B$ inhibitors by confocal microscopy. Expression of both NF- $k \mathrm{~B}$ p65 and p50 was reduced in the BAY1170-82 treated $B$ cells compared with that non treated $B$ cells (Figure 4A). In the same conditions, expression of BAFF-R was reduced but LY294002 and SP600125 were not reduced the expression of BAFF-R. These results demonstrated that the reduction of BAFF-R expression was derived from 


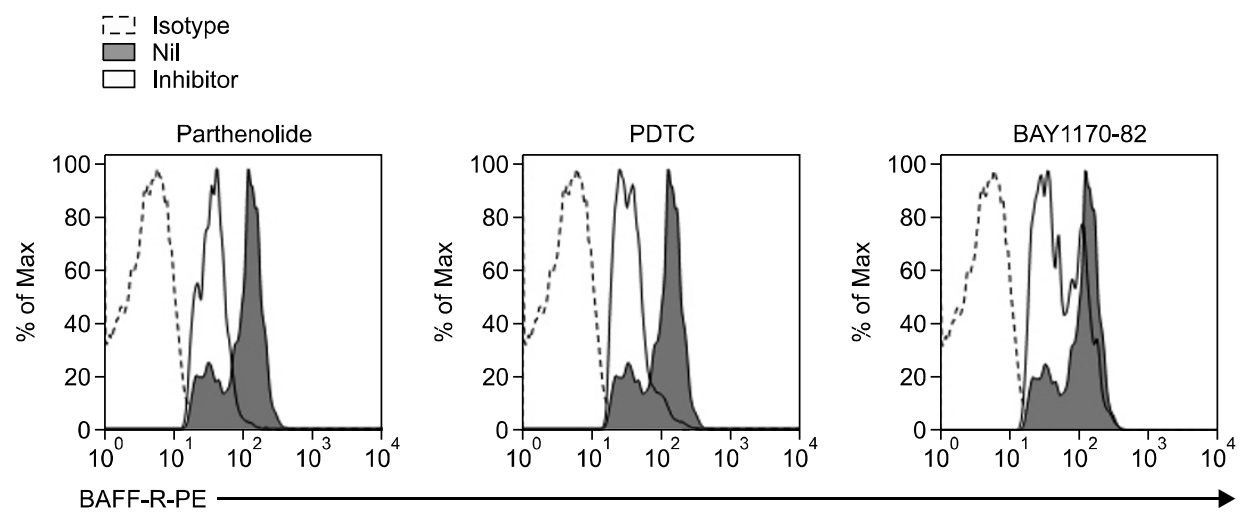

Figure 5. Effects of NF- $\kappa B$ pathway inhibitors on BAFF-R expression in PBMCs isolated from RA patients. PBMCs were cultured with parthenolide $(10 \mu \mathrm{M})$, PDTC $(0.5 \mu \mathrm{M})$, or BAY1170-82 $(10 \mu \mathrm{M})$ for $24 \mathrm{~h}$. Analysis of BAFF-R expression was performed using FACS. The results were confirmed by four independent experiments.

specific inhibition of $N F-\kappa B$ signaling pathway.

And then we focused on the NF- $k$ B shRNA for specific inhibition of NF- $\mathrm{BB}$ pathway. The confocal result showed that NF- $k B$ ShRNA treated $B$ cells were reduced BAFF-R compared with control ShRNA treated B cells (Figure 4B). And real time $P C R$ result showed reduction of $B A F F-R$ on $N F-\kappa B$ shRNA treated B cells (Figure 4C).

\section{Effect of NF- $x B$ inhibition on expression of BAFF-R in cells from RA patient}

We assessed the response of BAFF-R expression in RA PBMCs to NF- $\mathrm{BB}$ signal inhibitors. Isolated PBMCs from RA patients were cultured for $24 \mathrm{~h}$ with parthenolide $10 \mu \mathrm{M}$, PDTC $0.5 \mu \mathrm{M}$, or BAY1170$8210 \mu \mathrm{M}$, then cells were stained with PE antihuman BAFF-R and analyzed. BAFF-R expression was also significantly decreased compared with control in cells cultured with NF- $\kappa B$ signal inhibitors (Figure 5). The results were confirmed by four independent experiments.

\section{Discussion}

We demonstrated that inhibition of $N F-\kappa B$ promotes decreased expression of BAFF-R in human PBMC and peripheral $B$ cells. We also showed that inhibition of NF- $k B$ leads to decreased expression of BAFF-R in PBMCs from RA patients.

$N F-\kappa B$ plays a pivotal role in inflammation by virtue of its ability to induce transcription of an array of proinflammatory genes (Baeuerle and Henkel, 1994). In RA, NF- $k B$ is activated within the synovial tissue and contributes to cytokine production, adhesion molecule expression, and matrix metalloproteinase (MMP) activation (Aupperle et al., 2001).
BAFF is involved in the ectopic GC reaction in the RA synovium, and might contribute to the pathogenesis of RA, and BAFF and BAFF-R are widely expressed in the RA synovium (Nakajima et al., 2007). The primary role of BAFF in inflamed tissues is to support local $B$ cell and $T$ cell survival and activation. Blocking BAFF severely inhibits inflammation in an in vivo mouse model of RA (Wang et al., 2001).

We confirmed the higher expression of $N F-k B$ (p65 and p50), BAFF, and BAFF-R in severe RA synovium compared with mild RA and OA synovium. These data suggest that NF- $\kappa B$-targeted therapeutics might be effective in inflammatory diseases such as RA.

Because NF- $\kappa$ B controls the expression of Th1 cytokines IL-2, IFN $\gamma$, and IL-12, activation of NF- $\mathrm{BB}$ should facilitate Th1 subset development. However, NF- $k B$ is also important in $B$ cells via $B$ cell receptor (BCR) and $B A F F-R$ signaling. In $B$ cells, both $B C R$ and BAFF-R promote $B$ cell survival through NF- $\kappa$ B activation (Patke et al., 2004). BCR signaling induces $N F-\kappa B$ activation by the canonical pathway. T1 B cells are the most sensitive and have been shown to die in response to BCR cross-linking: this negative selection weeds out self-reactive $B$ cells. T2 B cells gain a second advantage for survival by responding to BAFF. T2 $B$ cells express higher levels of BAFF-R and display enhanced responsiveness to BAFF relative to T1 B cells (Castro et al., 2009).

In the canonical NF- $\mathrm{BB}$ pathway of $\mathrm{BCR}$ signaling, the IKK protein complex is critical for regulating $\mathrm{NF}-\kappa \mathrm{B}$ pathway activation. The IKK complex includes three important subunits: the catalytic subunits IKK $\alpha$ and IKK $\beta$ (also known as IKK1 and IKK2) and the regulatory subunit IKK $\gamma$ (also known as NEMO). Degradation of $I_{\kappa} B$ kinase proteins allows translocation of active c-Rel dimers to the 
nucleus (Patke et al., 2004).

However, downstream mediators of BAFF-R activation include both the canonical (classic, NF$\kappa B 1$ ) and alternative (noncanonical, NF- $k$ B2) NF$\kappa B$ pathways ( $\mathrm{Fu}$ et al., 2009). In the alternative pathway, activation of the IKK complex induces processing of precursor $p 100$ into p52, resulting in $N F-\kappa B$ subunit dimeric partners that migrate from the cytoplasm into the nucleus. In the nucleus, BAFF-R associates with IKK $\gamma$ and promotes histone $\mathrm{H} 3$ phosphorylation. BAFF-R, IKK $\beta$, and NF$\kappa \mathrm{B} / \mathrm{c}$-Rel form a nuclear complex binding to NF- $\kappa \mathrm{B}$ target gene promoters and regulating transcription of these genes (Patke et al., 2004).

A shared outcome of both BCR and BAFF-R signaling is $N F-k B$ activation. Although signaling through either the BCR or BAFF-R is individually capable of promoting $B$ cell survival, the simultaneous stimulation of both pathways has a synergistic effect on proliferation and maintenance (Patke et al., 2004; Castro et al., 2009). One mechanism could be the sequential induction of one pathway by the other in a positive feedback loop. This appears to be at least partially the case, because BAFF-R expression is upregulated in response to IgM stimulation in T2 and mature B cells, but not in T1 cells (Mackay and Browning, 2002).

Our results suggest that NF- $\kappa$ B blocking therapy could control $B$ cells via the reduction of BAFF-R expression.

By what mechanism does NF- $k$ B control BAFF-R expression? Castro et al. demonstrated that BCR signaling induced more long-term $\mathrm{C}$-Rel activation in T2 and mature B cells than in T1 B cells, leading to increased expression of antiapoptotic genes as well as prosurvival BAFF-R and its downstream substrate p100 (NF- $\kappa$ B2) (Castro et al., 2009). $\mathrm{BCR}$ signaling induces activation of nuclear c-Rel in T2 and follicular B cells. Activated nuclear c-Rel then regulates BCR-inducible expression of BAFF$R$ and substrate $p 100$ of the noncanonical NF- $k B$ pathway, thereby providing additional antiapoptotic functions in T2 B cells (Castro et al., 2009).

$\mathrm{Fu}$ et al. found that nuclear BAFF-R associates with the NF- $k B$ component $c-R e l$ and binds to the $\mathrm{NF}-\kappa \mathrm{B}$ binding site in the promoters of NF- $\kappa \mathrm{B}$ target genes such as BAFF, CD154, Bcl-xL, IL-8, and $\mathrm{Bfl}-1 / \mathrm{A} 1$, regulating the transcription of these genes (Fu et al., 2009). This finding indicates that BAFF-R can promote $B$ cell survival and proliferation by directly functioning as a transcription cofactor with other NF- $k B$ transcription factors and possibly regulating transcription. Thus, NF- $k \mathrm{~B}$ blocking therapy might reduce BAFF secretion.

In short, the anti-inflammatory mechanisms of
$\mathrm{NF}-\mathrm{kB}$ blocking therapy are complex and omnidirectional. The mechanisms relate to T cells, proinflammatory cytokines, autoantibody production, and $B$ cell survival through BAFF and BAFF-R signaling. NF- $k B$ blocking therapy is a promising method for solving the complex pathogenesis of RA.

\section{Methods}

\section{Immunohistochemistry of synovial tissues}

Immunohistochemical staining of $\mathrm{NF}-\kappa \mathrm{B}$ p65, NF- $\mathrm{B}$ p 50 , BAFF-R, and BAFF was performed on sections of synovium. The synovium samples were obtained from RA and osteoarthritis (OA) patients, fixed with $4 \%$ paraformaldehyde solution overnight at $4^{\circ} \mathrm{C}$, dehydrated with alcohol, washed, embedded in paraffin, and sectioned into $7 \mu \mathrm{m}$ slices. The sections were incubated overnight at $4^{\circ} \mathrm{C}$ with primary anti-NF- $k B$ p65 (Santa Cruz Biotechnology, Santa Cruz, CA), anti-NF- $k$ B p50 (Santa Cruz Biotechnology, Santa Cruz, CA), anti-BAFF-R (R\&D Systems, Minneapolis, $\mathrm{MN}$ ), anti-BAFF (Abcam, Cambridge, MA) antibodies, or irrelevant primary isotype-specific antibodies as a negative control. Slides were incubated with biotinylated anti-mouse IgG as secondary antibody for 20 min and then incubated with streptavidin-peroxidase complex (Vector Laboratories, Peterborough, UK) for $1 \mathrm{~h}$ followed by incubation with 3,3diaminobenzidine (Dako, Glostrup, Denmark). The sections were counterstained with hematoxylin. Slides were mounted in permanent mounting media (Dako, Glostrup, Denmark). Samples were photographed with an Olympus photomicroscope (Tokyo, Japan) (Richardson et al., 2008).

\section{Cells and reagents}

Peripheral blood was obtained with a heparin-treated syringe. Peripheral blood mononuclear cells (PBMCs) were isolated by density centrifugation using Ficoll-Hypaque (Pharmacia LKB, Uppsala, Sweden). B cell isolation kit II was used as recommended by the manufacturer (Miltenyi Biotec, Auburn, CA). CD19+ B cells were greater than $95 \%$. The purified cells were washed and suspended in RPMI 1640 medium (GibcoBRL, Carlsbad, CA) containing penicillin $(100 \mathrm{U} / \mathrm{ml})$, streptomycin $(100 \mu \mathrm{g} / \mathrm{ml})$, and $10 \%$ fetal bovine serum (GibcoBRL) that had been inactivated by heating to $56^{\circ} \mathrm{C}$ for $1 \mathrm{~h}$. The cell suspension was dispensed into 96-well plates (Nunc, Roskilde, Denmark) and incubated at $37^{\circ} \mathrm{C}$ in $5 \% \mathrm{CO}_{2}$. Pyrrolidine dithiocarbamate (PDTC; $0.5 \mu \mathrm{M}$ ) (Zhou et al., 2008) was purchased from Sigma-Aldrich (St. Louis, MO). Parthenolide $(10 \mu \mathrm{M})$ (Sheehan et al., 2002), LY294002 (1 $\mu \mathrm{M})$ (Ikezoe et al., 2007), and BAY 11-7082 (10 $\mu \mathrm{M})$ (O'Sullivan and Thomas, 2002) were purchased from Calbiochem (Schwalbach, Germany). SP600125 $(10 \mu \mathrm{M})$ (Xie et al., 2004) was purchased from A.G. Scientific (San Diego, CA). 


\section{Real-time polymerase chain reaction with SYBR Green}

mRNA was extracted using RNAzol B (BioTex Labs, San Antonio, TX) according to the manufacturer's instructions. Reverse transcription of $2 \mu \mathrm{g}$ of total mRNA was conducted at $42^{\circ} \mathrm{C}$ using the Superscript Reverse Transcription system (Takara, Shiga, Japan). Polymerase chain reaction (PCR) amplification of cDNA aliquots was performed by adding $2.5 \mathrm{mM}$ dNTPs and $2.5 \mathrm{U}$ Taq DNA polymerase (Takara), and human BAFF-R was amplified using the sense primer 5'- AGA CAA GGA CGC CCC AGA GCC C-3' and the anti-sense primer 5'- GTG GGG TGG TTC CTG GGT CTT C -3' in a Light Cycler TM (Roche Diagnostics Mannheim, Germany). The relative expression levels were calculated by normalizing the BAFF-R levels to the endogenously expressed housekeeping gene ( $\beta$-actin). Melting curve analysis was performed immediately after the amplification protocol under the following conditions: 0 $\mathrm{s}$ (hold time) at $95^{\circ} \mathrm{C}, 15 \mathrm{~s}$ at $65^{\circ} \mathrm{C}$, and $0 \mathrm{~s}$ (hold time) at $95^{\circ} \mathrm{C}$. The temperature change rate was $20^{\circ} \mathrm{C} / \mathrm{s}$ except in the final step, when it was $0.1^{\circ} \mathrm{C} / \mathrm{s}$. The crossing point (Cp) was defined as the maximum of the second derivative from the fluorescence curve.

\section{NF- $\ltimes B$ ShRNA}

Human NF- $k B$ shRNA was designed by Sigma-Aldrich. The sequence is CCGGCGAATGA CAGAGGCGTGTAT ACTCGAGTATACACGCCTCTGTCATTCGTTTTT. Human CD19+ B cells were plated in 24-well plates were transfected with $1 \mu \mathrm{g}$ or $2 \mu \mathrm{g}$ of shRNA using polyMAG and Magneto FACTOR Plate of Chemicell (Berlin,Germany) according the manufacturer's protocol.

\section{Flow cytometry}

PBMCs were incubated with human IgG to block the Fc receptor and then incubated with phycoerythrin (PE)conjugated anti-human BAFF-R (eBioscience, San Diego, CA) for $30 \mathrm{~min}$ at $4^{\circ} \mathrm{C}$. After washes, the cells were resuspended in phosphate-buffered saline and analyzed by flow cytometry (FACSCalibur; Becton Dickinson, San Diego, CA).

\section{Confocal microscopy}

Cytospins were made on the poly lysine-coated (SigmaAldrich) slides. Cells were fixed with acetone and blocked with $10 \%$ goat serum for $30 \mathrm{~min}$ at room temperature and stained with primary and secondary antibodies for overnight incubation at $4^{\circ} \mathrm{C}$. Primary antibodies anti-Human CD268 (BAFF Receptor) PE (eBioscience) and NF- $\kappa \mathrm{B}$ p65, p50 and the secondary antibody goat anti-rabbit IgG -FITC (Santa cruz) were used at 1:100 and 1:100 dilutions, respectively. Confocal images were acquired using a LSM 510 confocal microscope (Zeiss, Oberkochen, Germany).

\section{Statistical analysis}

The results are expressed as the mean \pm SEM. Statistical analysis was performed using Student's $t$ test and Wilco- xon signed-rank test. $P$ values $<0.05$ were regarded as significant.

\section{Acknowledgements}

This study was supported by a grant (A092258) from the Korea Healthcare Technology R\&D Project, Ministry for Health, Welfare, and Family Affairs, Republic of Korea, the National Research Foundation of Korea (NRF) Grant funded by the Korean Government (grant number 2007-0052153) and the Institute of Clinical Medicine Research of Bucheon St. Mary's Hospital

\section{References}

Aupperle K, Bennett B, Han Z, Boyle D, Manning A, Firestein G. NF-kappa B regulation by I kappa B kinase-2 in rheumatoid arthritis synoviocytes. J Immunol 2001;166: 2705-11

Baeuerle PA, Henkel T. Function and activation of NF-kappa $B$ in the immune system. Annu Rev Immunol 1994;12:141-79

Cambridge G, Leandro MJ, Edwards JC, Ehrenstein MR, Salden M, Bodman-Smith M, Webster AD. Serologic changes following B lymphocyte depletion therapy for rheumatoid arthritis. Arthritis Rheum 2003;48:2146-54

Castro I, Wright JA, Damdinsuren B, Hoek KL, Carlesso G, Shinners NP, Gerstein RM, Woodland RT, Sen R, Khan WN. $B$ cell receptor-mediated sustained $\mathrm{c}$-Rel activation facilitates late transitional $B$ cell survival through control of $B$ cell activating factor receptor and NF-kappaB2. J Immunol 2009;182:7729-37

Do RK, Hatada E, Lee H, Tourigny MR, Hilbert D, Chen-Kiang $\mathrm{S}$. Attenuation of apoptosis underlies B lymphocyte stimulator enhancement of humoral immune response. J Exp Med 2000;192:953-64

Enzler T, Bonizzi G, Silverman GJ, Otero DC, Widhopf GF, Anzelon-Mills A, Rickert RC, Karin M. Alternative and classical NF-kappa B signaling retain autoreactive B cells in the splenic marginal zone and result in lupus-like disease. Immunity 2006;25:403-15

Fu L, Lin-Lee YC, Pham LV, Tamayo AT, Yoshimura LC, Ford RJ. BAFF-R promotes cell proliferation and survival through interaction with IKKbeta and NF-kappaB/c-Rel in the nucleus of normal and neoplastic B-lymphoid cells. Blood 2009; 113:4627-36

Groom J, Kalled SL, Cutler AH, Olson C, Woodcock SA, Schneider P, Tschopp J, Cachero TG, Batten M, Wheway J, Mauri D, Cavill D, Gordon TP, Mackay CR, Mackay F. Association of BAFF/BLyS overexpression and altered B cell differentiation with Sjogren's syndrome. J Clin Invest 2002;109:59-68

Gross JA, Dillon SR, Mudri S, Johnston J, Littau A, Roque R, Rixon M, Schou O, Foley KP, Haugen H, McMillen S, Waggie K, Schreckhise RW, Shoemaker K, Vu T, Moore M, Grossman A, Clegg CH. TACl-Ig neutralizes molecules critical for $B$ cell development and autoimmune disease. impaired $B$ cell maturation in mice lacking BLyS. Immunity 2001;15:289- 
302

Ikezoe T, Nishioka C, Bandobashi K, Yang Y, Kuwayama Y, Adachi Y, Takeuchi T, Koeffler HP, Taguchi H. Longitudinal inhibition of PI3K/Akt/mTOR signaling by LY294002 and rapamycin induces growth arrest of adult T-cell leukemia cells. Leuk Res 2007;31:673-82

Jung S, Park YK, Lee H, Shin JH, Lee GR, Park SH. TGFbeta-treated presenting cells suppress collagen induced arthritis through the promotion of Th2 responses. Exp Mol Med 2010;42:187-94

Kim YH, Choi BH, Cheon HG, Do MS. B cell activation factor (BAFF) is a novel adipokine that links obesity and inflammation. Exp Mol Med 2009;41:208-16

Litinskiy MB, Nardelli B, Hilbert DM, He B, Schaffer A, Casali $P$, Cerutti A. DCs induce CD40-independent immunoglobulin class switching through BLyS and APRIL. Nat Immunol 2002;3:822-9

Mackay F, Browning JL. BAFF: a fundamental survival factor for B cells. Nat Rev Immunol 2002;2:465-75

Makarov SS. NF-kappa B in rheumatoid arthritis: a pivotal regulator of inflammation, hyperplasia, and tissue destruction. Arthritis Res 2001;3:200-6

Matsushita T, Fujimoto M, Hasegawa M, Matsushita Y, Komura K, Ogawa F, Watanabe R, Takehara K, Sato S. BAFF antagonist attenuates the development of skin fibrosis in tight-skin mice. J Invest Dermatol 2007;127:2772-80

Mayne CG, Amanna IJ, Nashold FE, Hayes CE. Systemic autoimmunity in BAFF-R-mutant A/WySnJ strain mice. Eur $\mathrm{J}$ Immunol 2008;38:587-98

Miagkov AV, Kovalenko DV, Brown CE, Didsbury JR, Cogswell JP, Stimpson SA, Baldwin AS, Makarov SS. NF-kappaB activation provides the potential link between inflammation and hyperplasia in the arthritic joint. Proc Natl Acad Sci U S A 1998;95:13859-64

Nakajima K, Itoh K, Nagatani K, Okawa-Takatsuji M, Fujii T, Kuroki H, Katsuragawa Y, Aotsuka S, Mimori A. Expression of BAFF and BAFF-R in the synovial tissue of patients with rheumatoid arthritis. Scand J Rheumatol 2007;36:365-72

Ng LG, Sutherland AP, Newton R, Qian F, Cachero TG, Scott ML, Thompson JS, Wheway J, Chtanova T, Groom J, Sutton IJ, Xin C, Tangye SG, Kalled SL, Mackay F, Mackay CR. B cell-activating factor belonging to the TNF family (BAFF)-R is the principal BAFF receptor facilitating BAFF costimulation of circulating T and B cells. J Immunol 2004;173:807-17

O'Sullivan BJ, Thomas R. CD40 ligation conditions dendritic cell antigen-presenting function through sustained activation of NF-kappaB. J Immunol 2002;168:5491-8

Patke A, Mecklenbrauker I, Tarakhovsky A. Survival signaling in resting B cells. Curr Opin Immunol 2004;16:251-5

Rahman ZS, Manser T. B cells expressing Bcl-2 and a signaling-impaired BAFF-specific receptor fail to mature and are deficient in the formation of lymphoid follicles and germinal centers. J Immunol 2004;173:6179-88

Rahman ZS, Rao SP, Kalled SL, Manser T. Normal induction but attenuated progression of germinal center responses in BAFF and BAFF-R signaling-deficient mice. J Exp Med 2003;198:1157-69

Richardson D, Pearson RG, Kurian N, Latif ML, Garle MJ, Barrett DA, Kendall DA, Scammell BE, Reeve AJ, Chapman $V$. Characterisation of the cannabinoid receptor system in synovial tissue and fluid in patients with osteoarthritis and rheumatoid arthritis. Arthritis Res Ther 2008;10:R43

Sheehan M, Wong HR, Hake PW, Malhotra V, O'Connor M, Zingarelli $B$. Parthenolide, an inhibitor of the nuclear factor-kappaB pathway, ameliorates cardiovascular derangement and outcome in endotoxic shock in rodents. Mol Pharmacol 2002;61:953-63

Tomita T, Takeuchi E, Tomita N, Morishita R, Kaneko M, Yamamoto K, Nakase T, Seki H, Kato K, Kaneda Y, Ochi T. Suppressed severity of collagen-induced arthritis by in vivo transfection of nuclear factor kappaB decoy oligodeoxynucleotides as a gene therapy. Arthritis Rheum 1999;42: 2532-42

Wang H, Marsters SA, Baker T, Chan B, Lee WP, Fu L, Tumas D, Yan M, Dixit VM, Ashkenazi A, Grewal IS. TACl-ligand interactions are required for $T$ cell activation and collageninduced arthritis in mice. Nat Immunol 2001;2:632-7

Xie Z, Singh M, Singh K. ERK1/2 and JNKs, but not p38 kinase, are involved in reactive oxygen species-mediated induction of osteopontin gene expression by angiotensin II and interleukin-1beta in adult rat cardiac fibroblasts. J Cell Physiol 2004;198:399-407

Zhang X, Park CS, Yoon SO, Li L, Hsu YM, Ambrose C, Choi YS. BAFF supports human B cell differentiation in the lymphoid follicles through distinct receptors. Int Immunol 2005;17:779-88

Zhou J, Zhang H, Gu P, Bai J, Margolick JB, Zhang Y. NF-kappaB pathway inhibitors preferentially inhibit breast cancer stem-like cells. Breast Cancer Res Treat 2008;111: 419-27 